\title{
A cloning vector able to replicate in Escherichia coli and Streptococcus sanguis
}

(Recombinant DNA; streptococcal shuttle plasmid; pACYC184; pVA749; pVA838)

\author{
Francis L. Macrina *, Janet Ash Tobian *, Kevin R. Jones *, R. Paul Evans *, and Don B. Clewell ** \\ * Department of Microbiology and Immunology, Virginia Commonwealth University, Richmond, VA 23298, and ** De* \\ partments of Oral Biology, and Microbiology and Immunology, Dental Research Institute, University of Michigan, Schools \\ of Medicine and Dentistry, Ann Arbor, MI 48109 (U.S.A.)
}

(Received March 15th, 1982)

(Revision received June 13th, 1982)

(Accepted July 15th, 1982)

\section{SUMMARY}

A plasmid that is able to replicate in both Escherichia coli and Streptococcus sanguis has been constructed by the in vitro joining of the pACYC184 $\left(\mathrm{Cm}^{r} \mathrm{Tc}^{r}\right)$ and pVA749 $\left(\mathrm{Em}^{r}\right)$ replicons. This plasmid, designated pVA838, is $9.2 \mathrm{~kb}$ in size and expresses $\mathrm{Em}^{r}$ in both $E$. coli and $S$. sanguis. Its $\mathrm{Cm}^{\mathrm{r}}$ marker is expressed only in $E$. coli and may be inactivated by addition of DNA inserts at its internal Eco RI or PouII sites. The pVA838 molecule also contains unique $S a l I, S p h I, B a m H I, N r u I$ and $X b a I$ cleavage sites suitable for molecular cloning. pVA838 may be amplified in $E$. coli but not in $S$. sanguis. We have used the pVA838 plasmid as a shuttle vector to clone streptococcal plasmid fragments in $E$. coli. Such chimeras isolated from $E$. coli were readily introduced into $S$. sanguis by transformation.

\section{INTRODUCTION}

Considerable effort has been applied recently to the development of molecular cloning systems that use a streptococcal host (Behnke and Gilmore, 1981; Macrina et al., 1980c; 1982; Malke et al.,

\footnotetext{
* Reprint requests and all correspondence should be addressed to Dr. F.L. Macrina.

Abbreviations: $\mathrm{CCC}$, covalently closed circular; $\mathrm{Cm}^{t}$, chloramphenicol resistance; $\mathrm{Cm}^{s}$, chloramphenicol sensitivity; $\mathrm{Em}^{r}$, erythromycin resistance; $\mathbf{E m}^{\mathbf{s}}$, erythromycin sensitivity; $\mathbf{k b}$, kilobase pairs; SDS, sodium dodecyl sulfate; $\mathrm{Tc}^{\mathrm{r}}$, tetracycline resistance: $\mathrm{Tc}^{s}$, tetracycline sensitivity; ::, novel joint; [], indicates plasmid-carrier state.
}

1981). Such systems have facilitated the study of streptococcal plasmid and chromosomal gene sequences. Using the transformable $S$. sanguis as a host, a number of streptococcal plasmid vectors have been constructed (Behnke and Gilmore, 1981; Macrina et al., 1980c; 1982; Malke et al., 1981). While the cloning of plasmid-derived sequences using such vectors has been straightforward, often chimeric plasmids bearing chromosomal inserts suffer deletions following their entry into the streptococcal cell. This problem appeared to be linked to the transformational requirements imposed on plasmids in the $S$. sanguis and $S$. pneumoniae systems. Namely, monomeric plasmid molecules transform with two-hit kinetics while 
oligomeric plasmid molecules transform with onehit kinetics (Macrina et al., 1981; Saunders and Guild, 1981). In the case of shotgun cloning, the existence of substantial amounts of a single specific chimera or specific multimers generated from a vector-chromosomal fragment mixture would be remote due to the large size of the genome. By contrast, plasmid-plasmid cloning experiments involved relatively few fragment combinations and, thus, appeared to give rise to the needed amounts of specific monomers or oligomeric chimeras.

Two strategies have been employed to improve the efficiency of cloning chromosomal gene fragments in the $S$. sanguis host system. First, we have adapted the "helper plasmid" method originally devised by Gryczan et al. (1980) for use in the Bacillus subtilis cloning system (Tobian and Macrina, 1982). This method allows for the recombinational rescue of incoming chimeras by a resident plasmid that is homologous with the vector.

A second strategy we have implemented to circumvent the inherent problems of "shotgun cloning" in streptococci has involved the construction of a shuttle plasmid vector. This plasmid is able to replicate and be used as a cloning vehicle in both $E$. coli and $S$. sanguis. Using this vector, chromosomal fragments first can be cloned in $E$. coli by standard recombinant DNA methodologies. Such $E$. coli-derived plasmid preparations containing oligomers as well as high monomer concentra- tions of chimeras would transform $S$. sanguis readily, presumably reducing the occurrence of deletion events. In this paper, we report on the construction, characterization and use of such a shuttle plasmid vector.

\section{MATERIALS AND METHODS}

\section{(a) Bacterial strains and media}

The principal bacterial strains employed in this work are described in Table I. E. coli strains were cultured in Penassay Broth (Difco Laboratories, Detroit, MI) or in M9 salts medium supplemented with $1.0 \%$ Casamino acids (Difco), $0.3 \%$ yeast extract (Difco) and 1\% glucose (Davis et al., 1980). LB-broth was used to grow $E$. coli prior to genetic transformation (Davis et al., 1980). Agar was added to a final concentration of $1.5 \%$ when solid medium was desired. Streptococci were cultured routinely in Todd Hewitt broth (Difco). Brain Heart Infusion (Difco) containing 1\% horse serum was used to grow streptococcal cells to the state of competence. Antibiotic-containing plates always were prepared using Todd Hewitt medium. Antibiotic concentrations employed in media were as follows: Tc, $10 \mu \mathrm{g} / \mathrm{ml} ; \mathrm{Cm}, 25 \mu \mathrm{g} / \mathrm{ml}$; $\mathrm{Em}, 10$ $\mu \mathrm{g} / \mathrm{ml}$.

\section{TABLE I}

Bacterial strains ${ }^{a}$

\begin{tabular}{|c|c|c|c|c|c|}
\hline Organism & Strain No. & $\begin{array}{l}\text { Relevant } \\
\text { phenotype }\end{array}$ & Plasmid & $\begin{array}{l}\text { Plasmid } \\
\text { size }\end{array}$ & $\begin{array}{l}\text { Comments / } \\
\text { reference }\end{array}$ \\
\hline Escherichia coli & V818 & $\mathrm{Thr}^{-} \mathrm{Leu}^{-} \mathrm{Thi}^{-}$ & $\begin{array}{l}\text { pACYCl84 } \\
\left(\mathrm{Cm}^{\mathrm{r}} \mathrm{Tc}^{\mathrm{r}}\right)\end{array}$ & $4 \mathrm{~kb}$ & $\begin{array}{l}\text { Chang and } \\
\text { Cohen. } 1978\end{array}$ \\
\hline Escherichia coli & V850 & $\begin{array}{l}\mathrm{Met}^{-} \mathrm{Thi}^{-} \mathrm{Gal}^{-} \\
\mathrm{Nal}^{\mathrm{r}} \mathrm{Rif}^{\mathrm{r}} \mathrm{HsdR}^{-} \\
\mathrm{Em}^{\mathrm{s}, \mathrm{b}}\end{array}$ & none & & $\begin{array}{l}\text { DB11 from } \\
\text { Julian Davies }\end{array}$ \\
\hline Streptococcus sanguis & V288 & & none & & strain Challis \\
\hline Streptococcus sanguis & V749 & & $\begin{array}{l}\text { pVA749 } \\
\left(\mathrm{Em}^{\mathrm{r}}\right)\end{array}$ & $5.2 \mathrm{~kb}$ & $\begin{array}{l}\text { Macrina et al., } \\
1982\end{array}$ \\
\hline
\end{tabular}

"Abbreviations: Phenotypes: $\mathrm{Thr}^{-}$, requires threonine; $\mathrm{Leu}^{-}$, requires leucine; $\mathrm{Thi}^{-}$, requires thiamine; $\mathrm{Met}^{-}$, requires methionine; $\mathrm{Gal}^{-}$, galactose non-fermenting; $\mathrm{Nal}^{\mathrm{r}}$, resistance to nalidixic acid (>50 $\mathrm{g} / \mathrm{ml}$ ); $\mathrm{Rif}^{\mathrm{r}}$, resistance to rifampicin $(>50 \mu \mathrm{g} / \mathrm{ml}$ ); HsdR $^{-}$, host specific restriction deficient.

${ }^{b}$ Carries mutation conferring hypersensitivity to antibiotics, including macrolide lincosamides, fusidic acid and puromycin. 


\section{(b) Plasmid DNA isolation and characterization}

CCC plasmid DNA was prepared by dyebuoyant density equilibrium centrifugation. The method of Clewell and Helinski (1970), was used for $E$. coli while that described by Macrina et al. (1980c) was used for S. sanguis. E. coli strains were rapidly screened for plasmid DNA by an adaption of a method obtained from M. Rosenberg (pers. communication). Cells from a 7-ml overnight Penassay broth culture were harvested by centrifugation and suspended in $0.7 \mathrm{ml}$ of a solution containing $15 \%$ sucrose, $50 \mathrm{mM}$ EDTA and 1 $\mathrm{mg} / \mathrm{ml}$ lysozyme. The cell suspension was transferred to a $1.5 \mathrm{ml}$ conical polypropylene centrifuge tube and incubated at $23^{\circ} \mathrm{C}$ for $10 \mathrm{~min} .30 \mu \mathrm{l}$ of $10 \% \operatorname{SDS}(\mathrm{w} / \mathrm{v}$ in water) then was added and the tube inverted gently three times. $50 \mu 1$ of $5 \mathrm{M}$ potassium acetate was added, mixed by gentle inversion and the tube incubated on ice for 30 min. The tube then was centrifuged at top speed in an eppendorf microfuge (Brinckmann Instruments) for $15 \mathrm{~min}$. About 300 to $500 \mu \mathrm{l}$ of the clear supernatant was carefully aspirated and transferred to a new 1.5-ml tube. $2 \mu 1$ of RNase (5 $\mathrm{mg} / \mathrm{ml}$, heated for $2 \mathrm{~min}$ in a boiling water bath prior to use) was added and the tube incubated for $15 \mathrm{~min}$ at $23^{\circ} \mathrm{C}$. The RNase-treated supernatant then was extracted once with $0.5 \mathrm{ml}$ of buffersaturated phenol. The aqueous phase was removed and extracted once with anhydrous ether. 2.5 vols. of ice-cold ethanol then were added to the supernatant, the tube mixed by inversion and centrifuged for $5 \mathrm{~min}$ in an eppendorf centrifuge. The supernatant was poured off and the tube was allowed to drain well over a paper towel. $100 \mu 1$ of water were added to the tube and the DNA pellet was dissolved by agitation on a Vortex mixer for $15 \mathrm{~s} .250 \mu 1$ of ice-cold extranol were added and the tube was incubated at $-70^{\circ} \mathrm{C}$ for at least 30 min. The precipitated DNA was pelleted by centrifugation in an eppendorf centrifuge, the supernatant poured off and the tube allowed to dry under vacuum for $15 \mathrm{~min}$. The DNA pellet was dissolved in $100 \mu 1 \mathrm{H}_{2} \mathrm{O} ; 10$ to $30 \mu 1$ of this preparation were sufficient for visualization of plasmid DNA on agarose gels; such preparations could be cleaved with restriction enzymes, if necessary. Streptococcal cells were screened for plasmid molecules by a previously described method (Macrina et al., 1980b). Plasmid copy number determination was performed according to our previously published methods (Macrina et al., 1980b; c).

Purified plasmid DNA or plasmid restriction digest products were analyzed by vertical agarose gel electrophoresis (Meyers et al., 1976) with appropriate size reference $\mathrm{CCC}$ or linear DNA ( HindIII cleaved $\lambda$ DNA) molecules (Macrina et al., 1978). Restriction endonucleases and T4 DNA ligase were purchased from Bethesda Research Laboratories (Gaithersburg, MD) and enzyme reactions were carried out as previously published (Macrina et al., 1980c). The conditions for DNA ligation and alkaline phosphatase treatment have been described (Macrina et al., 1980c).

\section{(c) Genetic techniques}

S. sanguis was genetically transformed according to the procedure of Lawson and Gooder (1970). $E$. coli was transformed by the standard $\mathrm{CaCl}_{2}$-heat shock method (Davis et al., 1980), except that cells were harvested at an absorbance of 0.2 (at $660 \mathrm{~nm}$ ) rather than 0.5. Plasmid segregation studies were performed according to Macrina et al. (1980a).

\section{RESULTS}

\section{(a) Construction of pVA838}

Two replicons were chosen to construct our Escherichia coli-Streptococcus shuttle plasmid. pACYC184, an E. coli plasmid vector was constructed by Chang and Cohen (1978). It is a multicopy chimeric plasmid, $4 \mathrm{~kb}$ in size, that bears $\mathrm{Tc}^{r}$ and $\mathrm{Cm}^{r}$ determinants. Its restriction cleavage site map is shown in Fig. 1. A unique EcoRI site occurs within its $\mathrm{Cm}^{\mathrm{r}}$ gene and unique HindIII, Bam HI, NruI, SphI and SalI sites occur within its $\mathrm{Tc}^{\mathrm{r}}$ determinant (see Fig. 1). pVA749 a chimeric streptococcal plasmid $5.2 \mathrm{~kb}$ in size, was described by Macrina et al. (1982); its restriction cleavage site map as well as the location of its single selective marker, $\mathrm{Em}^{\mathrm{r}}$, is also shown in Fig. 1. pVA749 and pACYC184 each were cleaved with 


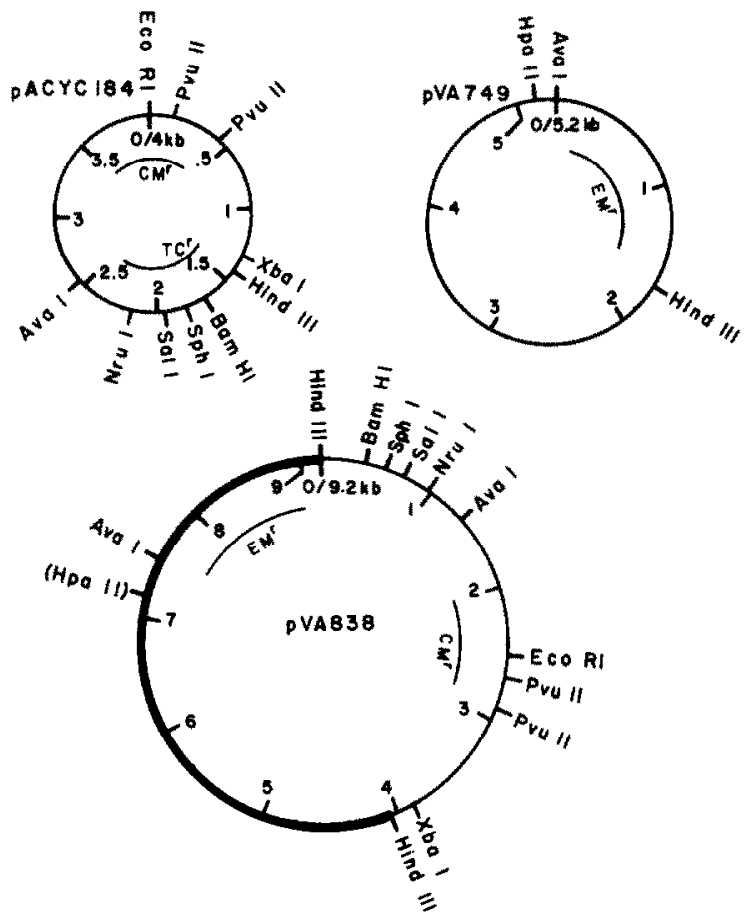

Fig. 1. Plasmid restriction maps. Coordinates (kb) are on the inside of each circular map. The approximate location of the $\mathrm{Em}^{\mathrm{r}}, \mathrm{Cm}^{\mathrm{r}}$ and $\mathrm{Tc}^{\mathrm{r}}$ determinants are indicated. The segments corresponding to pVA749 on the pVA838 chimera are denoted by the thick line. The non-unique Hpall site on pVA838 is shown in parentheses for purposes of physical reference.

HindIII, mixed in a ratio of $1: 1$ and ligated in vitro. Ligation products were used to transform $E$. coli V850 to $\mathrm{Cm}^{r}$. Several $\mathrm{Cm}^{r}$ transformants were screened for plasmid DNA and found to contain a 9.2-kb plasmid. Restriction enzyme analysis revealed these plasmids to be pVA749::pACYC184 chimeras. One such plasmid, designated pVA838, was characterized by restriction site mapping, and its cleavage map is seen in Fig. 1. Besides $\mathrm{Cm}^{\mathrm{r}}$ $\left(>25 \mu \mathrm{g} / \mathrm{ml}\right.$ ) pVA838 expressed $\mathrm{Em}^{\mathrm{r}}$ in $E$. coli V850. Its efficiency of plating on 10 and $40 \mu \mathrm{g} / \mathrm{ml}$ $\mathrm{Em}$ was $100 \%$. The $\mathrm{Tc}^{\mathrm{r}}$ marker was inactivated by the insertion of pVA749 into the pACYC184 HindIII site. Because the HindIII site of pACYC184 is known to reside in the promoter of the $\mathrm{Tc}^{\mathrm{r}}$ determinant (Stüber and Bujard, 1981) we attempted to restore the $\mathrm{Tc}^{t}$ phenotype by reversing the orientation of the pVA749 insert in pVA838. Accordingly, pVA838 was cleaved with $H$ indIII, self-ligated and used to transform $E$. coli V850, selecting for $\mathrm{Tc}^{r}$. No $\mathrm{Tc}^{r}$ clones were iso-
TABLE II

Sites for inserting DNA into pVA838

\begin{tabular}{|c|c|c|}
\hline Endonuclease & $\begin{array}{l}\text { Recognition } \\
\text { site }\end{array}$ & $\begin{array}{l}\text { Comments / refer- } \\
\text { ence }\end{array}$ \\
\hline$B a m \mathrm{HI}$ & $5^{\prime} \mathrm{G} \downarrow \mathrm{GATCC} 3^{\prime}$ & $\begin{array}{l}\text { Chang and Cohen, } \\
1978\end{array}$ \\
\hline Eco RI & $S^{\prime} \mathbf{G} \downarrow$ AATTC $3^{\prime}$ & $\begin{array}{l}\text { insertionally in- } \\
\text { activates } \mathrm{Cm}^{\mathrm{r}} \text { (Chang } \\
\text { and Cohen, 1978) }\end{array}$ \\
\hline NruI & $5^{\prime} \mathrm{TCG} \downarrow \mathrm{CGA} 3^{\prime}$ & $\begin{array}{l}\text { Schildkraut, I. and } \\
\text { Greenough, L.: cited } \\
\text { in New England Bio- } \\
\text { labs catalogue 1982- } \\
\text { 1983. Beverly, MA, } \\
\text { p. } 17\end{array}$ \\
\hline PvulI & $5^{\prime} \mathrm{CAG} \downarrow \mathrm{CTG} 3^{\prime}$ & $\begin{array}{l}\text { insertionally in- } \\
\text { activates } \mathrm{Cm}^{\mathrm{r}} \text {; blunt } \\
\text { end replacement of } \\
0.38-\mathrm{kb} \text { Pvull frag- } \\
\text { ment }\end{array}$ \\
\hline Sall & 5'G $\downarrow$ TCGAC3' & $\begin{array}{l}\text { Chang and Cohen, } \\
1978\end{array}$ \\
\hline SphI & $5^{\prime} \mathrm{GCATG} \perp \mathrm{C}^{\prime}$ & Fuchs et al., 1980 \\
\hline$X b a I$ & 5'T:CTAGA3' & $\begin{array}{l}\text { Thomsen and Stin- } \\
\text { ski, } 1981\end{array}$ \\
\hline
\end{tabular}

lated in several experiments. The hypothesis that mutations could be isolated that would restore $\mathrm{Tc}^{r}$ promoter function in pVA838 was also tested. In this regard, attempts to select $\mathrm{Tc}^{\mathrm{r}}$ mutants from $E$. coli [pVA838] were unsuccessful.

Data regarding sites for insertion of passenger DNA into either pACYC184 or pVA749 was compiled from studies done in several laboratories and this information appears in Table II. The Pvull sites (see Fig. 1) of pACYC184 were mapped in our laboratory; one lies within and the other just outside the $\mathrm{Cm}^{r}$ determinant. pACYC184 derivatives missing the $0.38-\mathrm{kb} P v u I I$ fragment, were able to replicate normally in $E$. coli but, as expected, were unable to confer $\mathrm{Cm}^{\mathrm{r}}$ (unpublished).

\section{(b) Transformation with pVA838}

pVA838 isolated from $E$. coli V850 was found to transform readily $S$. sanguis. $S$. sanguis cells carrying pVA838 failed to form colonies on 5 or $10 \mu \mathrm{g} / \mathrm{ml} \mathrm{Cm}$. An inoculum consisting of approx. $5 \times 10^{7}$ cells of $S$. sanguis[pVA838] showed a very 
TABLE III

Transformation of $E$. coli and $S$. sanguis ${ }^{2}$

\begin{tabular}{|c|c|c|c|c|}
\hline \multirow[t]{2}{*}{ Plasmid DNA } & \multirow[t]{2}{*}{ Origin } & \multirow[t]{2}{*}{ Recipient } & \multicolumn{2}{|c|}{ Transformation frequencies $b$} \\
\hline & & & $\mathrm{Cm}^{\mathrm{r}}$ & $\mathrm{Em}^{\mathrm{r}}$ \\
\hline pACYC184 & E. coli & E. coli & $8.2 \times 10^{-5}$ & - \\
\hline pVA838 & E. coli & E. coli & $8.2 \times 10^{-5}$ & $7.8 \times 10^{-5}$ \\
\hline pVA 838 & S. sanguis & E. coll & $6.0 \times 10^{-5}$ & $9.1 \times 10^{-5}$ \\
\hline pVA749 & S. sanguis & E. coli & - & $<10^{-8}$ \\
\hline pACYC 184 & E. coli & S. sanguis & $<10^{-8}$ & - \\
\hline pVA838 & E. coli & S. sanguis & $<10^{-8}$ & $3.2 \times 10^{-5}$ \\
\hline pVA 838 & S. sanguis & S. sanguis & $<10^{-8}$ & $4.0 \times 10^{-4}$ \\
\hline pVA749 & S. sanguis & S. sanguis & - & $1.0 \times 10^{-3}$ \\
\hline
\end{tabular}

${ }^{a}$ Competent cells were prepared as described in MATERIALS AND METHODS. In all cases, $0.25 \mu \mathrm{g}$ of plasmid DNA was added to competent cells. $E$. coli cells were incubated in L-broth for $90 \mathrm{~min}$ prior to plating on selective medium. Competent $S$. sanguis cells were exposed to DNA for $30 \mathrm{~min}$, treated with DNase $(10 \mu \mathrm{g} / \mathrm{ml})$ and plated on selective medium.

${ }^{\mathrm{b}}$ For $S$. sanguis, frequency was expressed as transformants/recipient at time DNA was added. For $E$. coli, frequency was expressed as transformants/surviving cell following $2 \mathrm{~min}$ of $42^{\circ} \mathrm{C}$ heat shock.

faint lawn of growth following $48 \mathrm{~h}$ incubation on $5 \mu \mathrm{g} / \mathrm{ml}$ of $\mathrm{Cm}$. In addition, S. sanguis[pVA838] showed about a $10 \%$ plating efficiency on $1 \mu \mathrm{g} / \mathrm{ml}$ Cm. S. sanguis V288 (devoid of pVA838) failed to display either of these characteristics. The $\mathrm{Em}^{\mathrm{r}}$ conferred by pVA838 was fully expressed in $S$. sanguis. S. sanguis[pVA838] plated at $100 \%$ efficiency on 10 through $200 \mu \mathrm{g} / \mathrm{ml} \mathrm{Em}$. Comparative transformation frequencies using pVA838 isolated from $E$. coli or $S$. sanguis are shown in Table III.

\section{(c) Genetic and physical characterization of pVA838}

The genetic stability of pVA838 was examined in $E$. coli V850 and S. sanguis V288, following two serial passages in drug-free broth cultures grown at $37^{\circ} \mathrm{C}$. In addition, the stabilities of pVA749 and pACYC184 were similarly determined. pVA749 was stable in $S$. sanguis showing a frequency of loss of $<0.1 \%$. pACYC184 was lost at a frequency of about $1 \%$ from $E$. coli V850. pVA838 was lost at a frequency of about $8-9 \%$ from $E$. coli V850 but

\section{TABLE IV}

Plasmid copy numbers

\begin{tabular}{|c|c|c|c|c|c|}
\hline \multirow[t]{3}{*}{ Strain } & \multirow[t]{3}{*}{ Plasmid } & \multicolumn{4}{|c|}{ Plasmid copies/chromosomal equivalent ${ }^{\text {a }}$} \\
\hline & & \multicolumn{2}{|c|}{ Penassay or Todd Hewitt broth ${ }^{b}$} & \multicolumn{2}{|c|}{ Supplemented M 9 broth } \\
\hline & & Unamplified & Amplified $^{c}$ & Unamplified & Amplified ${ }^{c}$ \\
\hline E. coli $\mathrm{V} 855^{\mathrm{d}}$ & pACYC184 & $16 \pm 1.9$ & $51 \pm 6.0$ & $21 \pm 3$ & $330 \pm 21$ \\
\hline E. coli V854 ${ }^{\mathrm{d}}$ & pVA 838 & $8 \pm 0.9$ & $21 \pm 2.0$ & $11 \pm 1.0$ & $37 \pm 4.0$ \\
\hline S. sanguis $\mathrm{V} 749$ & pVA749 & $19 \pm 1.1$ & $14 \pm 1.1$ & not done & not done \\
\hline S. sanguis V839 & pVA838 & $15 \pm 1.1$ & $11 \pm 1.4$ & not done & not done \\
\hline
\end{tabular}

${ }^{a}$ Chromosome sizes are taken as $2.5 \times 10^{9}$ daltons for $E$. coli (Cooper and Helmstetter, 1968) and $1.8 \times 10^{9}$ daltons for $S$. sanguis (Macrina et al, 1977). Numbers represent averages $=$ standard deviation of at least three experiments.

${ }^{b} E$. coli was grown in Penassay broth, $S$. sanguis in Todd Hewitt broth.

${ }^{c}$ Mid $\log$ phase cells were treated with either spectinomycin $(300 \mu \mathrm{g} / \mathrm{ml}$ for E. coli) or chloramphenicol ( $300 \mu \mathrm{g} / \mathrm{ml}$ for $S$. sanguis) for $8 \mathrm{~h}$ prior to preparation of crude cell lysates.

${ }^{d} E$. coli V850 carrying pACYC184 or pVA838. 
was stably maintained in $S$. sanguis V288 (frequency of loss $<0.1 \%$ ).

As can be seen in Table IV, the copy number of pVA838 was depressed relative to pACYC184 in E. coli. The pVA838 copy number in S. sanguis approached that of pVA749, however. pVA838 could be amplified in $E$. coll by treatment of mid-log grown cells with drugs that blocked protein synthesis. In Penassay broth-grown cells, pACYC184 showed about a 3-fold increase in copy number under standard conditions $(8 \mathrm{~h}$ of spectinomycin treatment). pVA838 showed about a $2 \frac{1}{2}$-fold increase. Neither pVA749 nor pVA838 showed an increase in copy number in $S$, sanguis cells treated with $\mathrm{Cm}$ (or spectinomycin, data not shown).

Plasmid amplification properties in $E$. coli could be altered by growth of cells in a supplemented M9-salts broth (Table IV). The unamplified copy numbers of pACYC184 and pVA838 were unremarkable as compared to Penassay broth-grown cells. However, pACYC184 showed an approx. 15-fold increase in copy number in spectinomycintreated cells. pVA838, on the other hand, showed slightly over a 3-fold increase in copy number in comparably treated $E$. coli cells.

\section{(d) Use of pVA838 as a shuttle cloning vehicle}

To directly test the utility of pVA838 we chose to use it to clone fragments of the streptococcal plasmid pPD1. This plasmid is $M_{\mathrm{r}} 35 \times 10^{6}$ in size and confers conjugative donor ability and bacteriocin production in $S$. faecalis (Clewell, 1981, and unpublished). In addition, pPD1-containing donor cells respond to the sex pheromone system of $S$. faecalis; i.e., donor cells carrying pPDI form aggregates when exposed to a small peptide

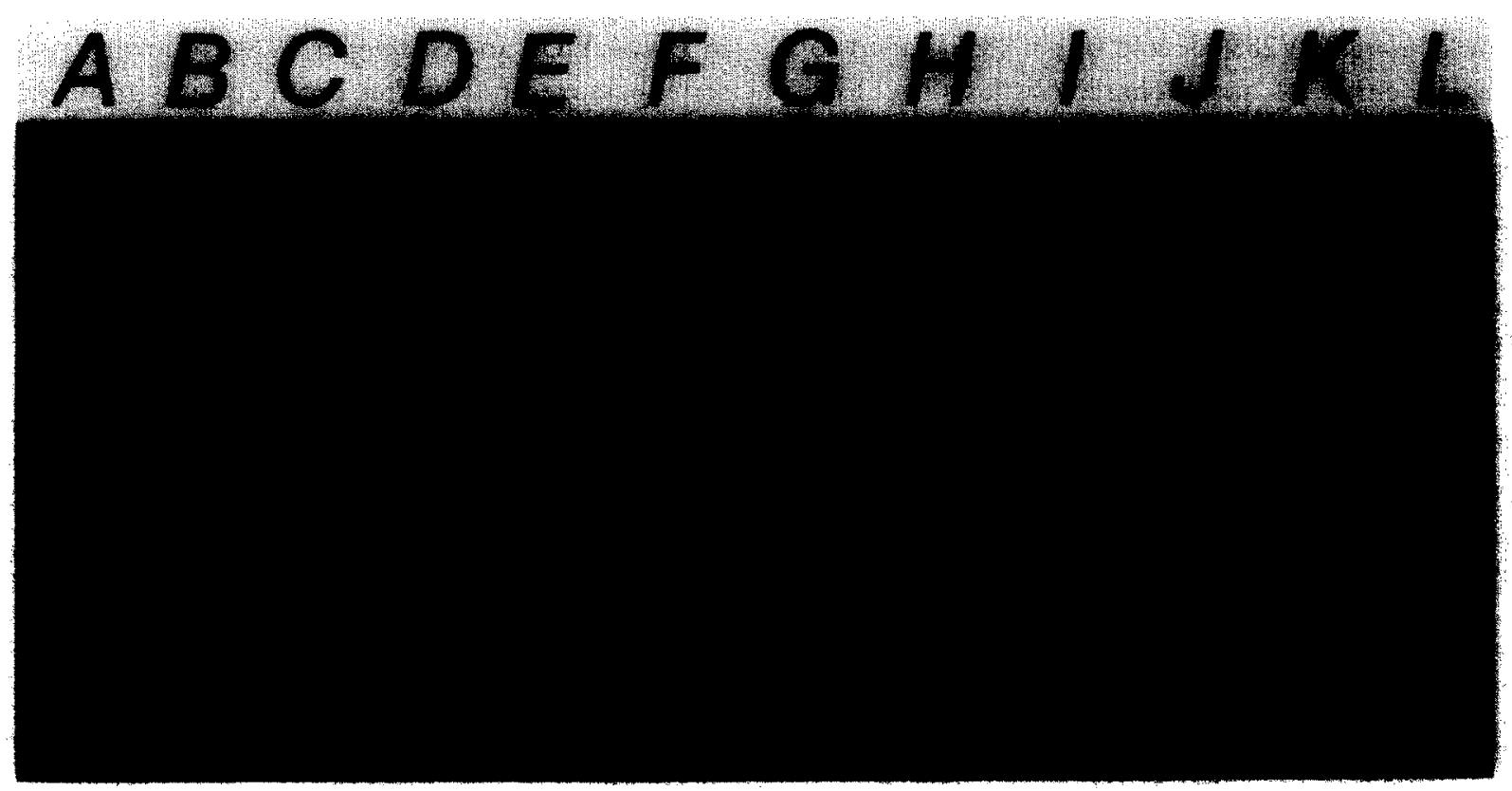

Fig. 2. Analysis of recombinant pPDI:: pVA838 plasmids (see RESULTS, section d). Plasmid DNAs were cleaved with either Eco RI (lanes A-E, J-L) or AvaI (lanes F-H) and electrophoresed through 0.7\% agarose. (A) Linear pVA838 (9.2-kb). (B) Eco RI cleavage products of pVA860: 9.2-kb pVA838 and 6.6-kb EcoRI-D fragment of pPDI. (C) EcoRI cleavage products of pVA861: 9.2-kb pVA838 and 5.1-kb EcoRI-E fragment of pPD1 (uppermost band is the partially digested [i.e., linear] pVA861). (D) Eco RI cleavage products of pVA862: both fragments [pVA838 and EcoRI-C fragment of pPDI] are 9.2-kb. (E) EcoRI cleavage products of pPD1. (F-H) Aval cleavage products of pVA860,861, and 862 respectively. The common fragment corresponds to the $A v a l-B$ fragment of pVA838 (kb coordinates 7.5 to 1.3; see Fig. 1). The EcoRI-D fragment of pPDI is known to contain an AvaI site (J. Shaw and D. Clewell, unpublished) and this accounts for the three components seen in lane F: (I) Phage $\lambda$ DNA cleaved with HindIII; fragment sizes, top to bottom, are $23.7 \mathrm{~kb}, 9.46 \mathrm{~kb}, 6.75 \mathrm{~kb}, 4.26 \mathrm{~kb}, 2.26 \mathrm{~kb}$ and 1.98-kb. (J) pVA838 cleaved with EcoRI. (K) pPDI cleaved with EcoRI. (L) pVA876 EcoRI cleavage products: $9.2-\mathrm{kb}$ pVA838 and 12.1-kb Eco RI-B fragment of pPD1. 
[pheromone] synthesized by recipient strains. pPD1 was cleaved into five fragments by $E c o$ RI $(21.2 \mathrm{~kb}$, $12.1 \mathrm{~kb}, 9.2 \mathrm{~kb}, 6.6 \mathrm{~kb}$ and $5.1 \mathrm{~kb}$, see Fig. 2). $E c o$ RI-cleaved pVA838 (approx. $1.5 \mu \mathrm{g}$ ) that had been treated with alkaline phosphatase was mixed with approx. $0.5 \mu \mathrm{g}$ of EcoRI-cleaved pPD1. Following ligation, this mixture was used to transform E. coli V850 to $\mathrm{Em}^{\mathrm{r}}\left(\mathrm{Em}^{\mathrm{r}}\right.$ transformants were recovered at a frequency of approx. $10^{-6}$ /survivor). Greater than $80 \%$ of all $\mathrm{Em}^{\mathrm{r}}$ transformants, were $\mathrm{Cm}^{\mathrm{s}}$. From these transformants, recombinant plasmids representing pVA838::pPD1 EcoRI-C, pVA838::pPD1 EcoRI-D, and pVA838::pPD1 EcoRI-E chimeras were detected (see Fig. 2, lanes B-D, F-H). In a separate experiment electrophoretically purified pPD1 EcoRI-B fragment was ligated to EcoRI-cleaved, alkaline phosphatasetreated pVA838. $\mathrm{Em}^{\mathrm{r}}$ transformants were recovered at a low frequency (approx. $5 \times 10^{-7}$ ) and several $\mathrm{Cm}^{\mathrm{s}}$ clones were analyzed and found to contain pVA838::pPD1 EcoRI-B chimeras (Fig. 2, lanes $\mathbf{J}-\mathrm{L}$ ).

The pVA838-derivatives bearing either pPD1 EcoRI-B, C, D or E fragments could be readily transformed into $S$. sanguis V288 at frequencies of approx. $10^{-5}$ per recipient by selecting for $\mathrm{Em}^{\mathrm{r}}$. Such transformants revealed plasmids that were indistinguishable in size from the transforming molecules. $E$. coli and $S$. sanguis clones bearing these chimeric plasmids (i.e., carrying either pPD1 EcoRI-B, C, D or E) were tested for ability to elaborate the PPD1 bacteriocin or for their ability to aggregate when exposed to a $S$. faecalis pheromone-producing recipient strain. Neither bacteriocin production nor pheromone-induced aggregation were expressed in $E$. coli or $S$. sanguis host strains containing any of the cloned pPD1 fragments.

\section{DISCUSSION}

The Escherichia-Streptococcus shuttle plasmid cloning vehicle described in this paper adds an important dimension to the available recombinant DNA systems of the streptococci. Problems associated with the uptake and processing of transforming DNA in the $S$. sanguis host have made the cloning of fragments derived from large DNA molecules (i.e., genomic DNA) difficult. The use of a shuttle plasmid to approach genomic shotgun cloning in the streptococci reduces problems associated with the requirements for the high chimeric monomer concentrations needed to effect two-hit kinetics or for the presence of chimeric oligomers bearing a specific insert. The shuttle plasmid can be used to first construct a streptococcal chromosomal fragment library in $E$. coli. Chimeric plasmids so obtained can then be introduced into $S$. sanguis by transformation. Because any given chimera would represent a homogeneous molecular population, it would transform $S$. sanguis by the normal pathways utilized for a monomeric or oligomeric plasmid species with minimal risk of deletion formation (Saunders and Guild, 1981). Although we have demonstrated the utility of the shuttle plasmid using passenger DNA of streptococcal plasmid origin, we also have successfully employed this system to clone chromosomal fragments from $S$. mutans and $S$. faecalis into $E$. coli. These plasmids were in turn, successfully introduced into $S$. sanguis by genetic transformation (J.A.T. and F.L.M. in preparation).

We have developed our shuttle system around the use of an antibiotic-hyper-sensitive $E$. coli mutant (Table I) so as to be able to use the $\mathrm{Em}^{\mathrm{r}}$ marker of pVA749 in this species. Indeed, most commonly used $E$. coli strains can be inhibited by concentrations of 50 to $150 \mu \mathrm{g} / \mathrm{ml} \mathrm{Em}$. In these strains (e.g., E. coli C600), the $\mathrm{Em}^{\mathrm{r}}$ marker of pVA838 was expressed so as to confer resistance to Em at such drug levels (unpublished). Thus, the pVA838 plasmid may be introduced into and phenotypically identified in most strains of $E$. coli. We have not yet closely examined the problem of pVA838 $\mathrm{Cm}^{r}$ expression in $S$. sanguis. The plating efficiency of $S$. sanguis [pVA838] on low $\mathrm{Cm}$ concentrations does suggest that the $\mathrm{Cm}^{r}$ gene is being transcribed and translated. However, this marker cannot be used in any practical way in the $S$. sanguis host at present. Attempts to select moderate or high level $\mathrm{Cm}^{r}$ mutants of $S$. sanguis[pVA838] have not been fruitful.

pVA838 DNA isolated from either host can be transformed readily into $E$. coli or $S$. sanguis (Table III). Transformation frequencies using $S$. sanguis as a host were consistently higher using $S$. 
sanguis-derived vs. E. coli-derived pVA838. This may be the result of host-specified restriction; such effects, however, do not significantly impair the functionality of the shuttle system. Studies on plasmid segregation revealed pVA838 to be significantly less stable in $E$. coli (frequency of loss under non-selective conditions, $\sim 8-9 \%$ ) than in $S$. sanguis. The pACYC184 replicon has been reported to be unstable in $E$. coli (Meacock and Cohen, 1980) and the addition of the pVA749 molecule to this replicon appears to have exaggerated this instability for unknown reasons (1\% vs. $8-9 \%$ loss). In any event, problems with plasmid loss can be effectively and easily dealt with by the constant use of selective pressure (i.e., Fm or $\mathrm{Cm}$ ) on pVA838-harboring cells.

The copy number of pVA838 in $E$. coli V850 is depressed as compared to pACYC184 (Table IV). Both pVA838 and pACYC184 were amplifiable in the absence of protein synthesis (Table IV, columns 2 and 4). These studies (Table IV) revealed the existence of media-specific effects on amplification. Supplemented M9 broth clearly is the medium of choice for amplification of pVA838. The physiologic bases for the superior amplification in supplemented M9 medium remains unclear but somewhat similar observations have been reported for ColE1 (Clewell, 1972) and pBR322 (Norgard et al., 1979) amplification. Consistent with our previous findings for pVA749, the pVA838 shuttle plasmid failed to replicate in the absence of protein synthesis in $S$. sanguis. (Macrina et al., 1982).

Plasmid pVA838 offers a reasonable number of sites for cloning DNA inserts (Table II). Particularly useful are the EcoRI and PvuII sites that afford insertional inactivation of the $\mathrm{Cm}^{\mathrm{r}}$ determinant. PvuII cleaves to yield blunt-ended molecules thereby allowing one to insert such a molecule formed by any nucleolytic process (blunt-endedcutting restriction endonucleases, $\mathrm{S} 1$, and BAL31 nucleases). Although the Bam HI, SalI and $X b a I$ cleavage sites of pVA838 do not permit insertional inactivation, molecules cleaved with these enzymes can be treated with alkaline phosphatase to improve recombinant yields. It should be noted that recently Thomsen and Stinski (1981) have cloned fragments as large as $35 \mathrm{~kb}$ into the $\mathrm{XbaI}$ site of $\mathrm{pACYCl} 184$. Although the largest fragment we have yet to clone into pVA838 was $12.1 \mathrm{~kb}$, this would not seem to be an upper limit.

Plasmid pVA838 is clearly a functional shuttle replicon within the context that it was conceived. However, certain improvements in its design are obvious and desirable. In this connection, we are currently attempting to construct smaller derivatives of pVA838. The restoration of the insertionally inactivatable $\mathrm{Tc}^{r}$ gene would also be desirable. We have recently constructed a chimera consisting of pVA749 and pACYC184 joined at their AvaI sites (see Fig. 1). This recombinant plasmid was exceedingly unstable in non-selectively grown $E$. coli cells. We believe this is due to the fact that the pACYC184 Aval site is at or near sequences governing pACYC184 replicative functions (See Meacock and Cohen, 1980). Attempts to obtain stable derivatives of this plasmid are underway. It does, however, express both the $\mathrm{Tc}^{\mathrm{r}}$ and $\mathrm{Cm}^{r}$ genes in $E$. coli thus providing two different insertional inactivation strategies (Fig. 1 and Chang and Cohen, 1978).

\section{ACKNOWLEDGEMENTS}

This work was supported by USPHS Grants DE04224 to F.L.M. and DE02731 and AI10318 to D.B.C. and by the Consumer Products Group of the Warner-Lambert Company. F.L.M. is the recipient of Research Career Development Award DE00081 from the National Institute for Dental Research. The helpful suggestions of Dr. D. Behnke are gratefully acknowledged. We are indebted to Jay Shaw who kindly provided his unpublished information on the restriction cleavage analysis of pPDI and to Dr. Julian Davies for supplying us with $E$. coli DB 11.

\section{REFERENCES}

Behnke, D. and Gilmore, M.S.: Location of antibiotic resistance determinants, copy control and replication functions on the double selective streptococcal cloning vector pGB301. Mol. Gen. Genet. 184(1981) 115-120.

Chang, A.C.Y, and Cohen, S.N.: Construction and characterization of amplifiable multicopy DNA cloning vehicles de- 
rived from the P15A cryptic miniplasmid. J. Bacteriol. 134(1978) 1141-1156.

Clewell, D.B. and Helinski, D.R.: Properties of a deoxyribonucleic acid-protein relaxation complex and strand specificity of the relaxation event. Biochemistry 9(1970) 4428-4440.

Clewell, D.B.: Nature of ColEl plasmid replication in Escherichia coli in the presence of chloramphenicol. J. Bacteriol. 110(1972) 667-676.

Clewell, D.: Plasmids, drug resistance and gene transfer in the genus Streptococcus. Microbiol. Rev. 45(1981) 409-436.

Cooper, S. and Helmstetter, C.: Chromosome replication and the division cycle of $E$. coli B/r. J. Mol. Biol. 31(1968) 519-540.

Davis, R.W., Botstein, D. and Roth, J.L.: A Manual for Genetic Engineering: Advanced Bacterial Genetics. Cold Spring Harbor Laboratory, Cold Spring Harbor, N.Y., 1980, pp. 140-141, 201, 203.

Fuchs, L.Y., Covarrubias, L., Escalante, L., Sanchez, S. and Bolivar, F.: Characterization of a site-specific restriction endonuclease SphI from Streptomyces phaeochromogenes. Gene 10(1980) 39-46.

Gryczan, T., Contente, S. and Dubnau, D.: Molecular cloning of heterologous chromosomal DNA by recombination between a plasmid vector and a homologous resident plasmid in Bacillus subtilis. Mol. Gen. Genet. 177(1980) 459-467.

Lawson, J. and Gooder, H.: Growth and development of competence in the group $\mathrm{H}$ streptococci. J. Bacteriol. 102(1970) 820-825.

Macrina, F.L., Reider, J.L., Virgili, S.S. and Kopecko, D.J.: Survey of the extrachromosomal gene pool of Streptococcus mutans. Infect. Immun. 17(1977) 215-226.

Macrina, F.L., Kopecko, D.J., Jones, K.R., Ayers, D.J. and McCowen, S.M.: A multiple plasmid-containing Escherichia coli strain: convenient source of size reference plasmid molecules. Plasmid 1(1978) 417-420.

Macrina, F.L., Keeler, C.L., Jones, K.R. and Wood, P.H.: Molecular characterization of unique deletion mutants of the streptococcal plasmid pAM $\beta 1$. Plasmid 4(1980a) 8-16.

Macrina, F.L., Wood, P.H. and Jones, K.R.: Simple method for demonstrating small plasmid deoxyribonucleic acid molecules in oral streptococci. Appl. Environ. Microbiol. 39(1980b) 1070-1073.
Macrina, F.L., Jones, K.R. and Wood, P.H.: Chimeric streptococcal plasmids and their use as molecular cloning vehicles in Streptococcus sanguis (Challis). J. Bacteriol. 143(1980c) 1425-1435.

Macrina, F.L., Jones, K.R. and Welch, R.A.: Transformation of Streptococcus sanguis with monomeric pVA736 plasmid deoxyribonucleic acid. J. Bacteriol. 146(1981) 826-830.

Macrina, F.L., Tobian, J.A., Jones, K.R. and Evans, R.P.: Molecular cloning in the streptococci, in Hollaender, A, DeMoss, R., Kaplan, S., Konisky, J., Savage, D., and Wolfe, R. (Eds.). Genetic Engineering of Micro-organisms for Chemicals, Plenum, New York, 1982, pp. 195-210.

Malke, H., Burman, L.G. and Holm, S.E.: Molecular cloning in streptococci: physical mapping of the vehicle plasmid pSM10 and demonstration of intergroup transfer. Mol. Gen. Genet. 181 (1981) 254-267.

Meacock, P.A. and Cohen, S.N.: Partitioning of bacterial plasmids during cell division: a cis-acting locus that accomplishes stable plasmid inheritance. Cell 20(1980) 529-542.

Meyers, J.A., Sanchez, D., Elwell, L.P. and Falkow, S.: Simple agarose gel electrophoretic method for the identification and characterization of plasmid deoxyribonucleic acid. J. Bacteriol. 127(1976) 1529-1537.

Norgard, M.V., Emigholz, K. and Monahan, J.J.: Increased amplification of pBR322 plasmid deoxyribonucleic acid in Escherichia coli strains RR 1 and $\chi 1776$ grown in the presence of high concentrations of nucleoside. J. Bacteriol. 138(1979) 270-272.

Saunders, C.W. and Guild, W.: Pathway of plasmid transformation in Pneumococcus: open circular and linear molecules are active. J. Bacteriol. 146(1981) 517-526.

Stüber, D. and Bujard, H.: Organization of transcriptional signals in plasmids pBR322 and pACYC184. Proc. Natl. Acad. Sci. USA 78(1981) 167-171.

Thomsen, D.R. and Stinski. M.F.: Cloning of the human cytomegalovirus genome as endonuclease $\mathrm{XbaI}$ fragments. Gene 16(1981) 207-216.

Tobian, J.A. and Macrina, F.L.: Helper plasmid cloning in Streptococcus sanguis: cloning of a tetracycline resistance determinant from the Streptococcus mutans chromosome. J. Bacteriol (1982) in press.

Communicated by F.E. Young. 